\title{
Manipulating Phosphorus, Calcium, and Magnesium Utilization by Growing Lambs Using Natural Zeolite (Clinoptilolite)
}

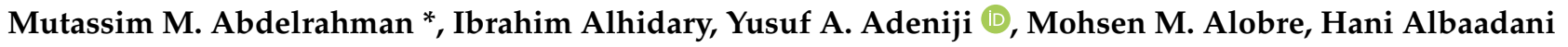 \\ and Riyadh Aljumaah \\ Department of Animal Production, Faculty of Food and Agriculture Sciences, King Saud University, \\ P.O. Box 2460, Riyadh 11451, Saudi Arabia; ialhydari@ksu.edu.sa (I.A.); sfadeniji@gmail.com (Y.A.A.); \\ mohsenalobre@gmail.com (M.M.A.); hanie781@gmail.com (H.A.); raljumaah@ksu.edu.sa (R.A.) \\ * Correspondence: amutassim@ksu.edu.sa
}

check for updates

Citation: Abdelrahman, M.M.; Alhidary, I.; Adeniji, Y.A.; Alobre, M.M.; Albaadani, H.; Aljumaah, R. Manipulating Phosphorus, Calcium, and Magnesium Utilization by Growing Lambs Using Natural Zeolite (Clinoptilolite). Sustainability 2021, 13, 1539. https://doi.org/10.3390/ su13031539

Academic Editor: Yusuf G. Adewuyi Received: 21 December 2020

Accepted: 25 January 2021

Published: 1 February 2021

Publisher's Note: MDPI stays neutral with regard to jurisdictional claims in published maps and institutional affiliations.

Copyright: (c) 2021 by the authors. Licensee MDPI, Basel, Switzerland. This article is an open access article distributed under the terms and conditions of the Creative Commons Attribution (CC BY) license (https:/ / creativecommons.org/licenses/by/ $4.0 /)$.

\begin{abstract}
A total of 24 three-month-old lambs with an average weight of $23 \pm 1.5 \mathrm{~kg}$ were used in this study and fed a complete diet supplemented with natural zeolite at $1 \%$ and $2 \%$ of feed weight to evaluate the effect of zeolite on calcium (Ca), phosphorus $(\mathrm{P})$, and magnesium $(\mathrm{Mg})$ concentration in tissues (kidney, liver, and muscle), rumen fluid, and blood. Adding zeolite at $2 \%$ to the diet resulted in an increase $(p<0.05)$ in body weight but a depressed feed conversion ratio. Phosphorus digestibility was significantly $(p<0.05)$ increased with the addition of zeolite while the digestibility of $\mathrm{Ca}$ and $\mathrm{Mg}$ remained unaffected $(p>0.05)$. The concentration of $\mathrm{Ca}, \mathrm{Mg}$, and $\mathrm{P}$ in the liver remained unchanged $(p>0.05)$ with the addition of zeolite. The addition of zeolite led to a decrease $(p<0.05)$ in the Ca concentration in the kidney and muscle, whereas the Ca concentration in lambs receiving diets supplemented with $2 \%$ zeolite $(123.13$ and $48.49 \mu \mathrm{g} / \mathrm{g})$ was significantly $(p<0.05)$ higher than supplementation at $1 \%$ (120.13 and $45.66 \mu \mathrm{g} / \mathrm{g}$, respectively, for kidney and muscle). Furthermore, serum and rumen fluid concentrations of $\mathrm{P}, \mathrm{Ca}$, and $\mathrm{Mg}$ exhibited no significant differences upon the addition of zeolite to the diet. Conclusively, diet supplementation by zeolite at $2 \%$ improves performance and especially $\mathrm{P}$ digestibility, which may result in the reduction in minerals in lambs' waste and consequently a reduction in environmental pollution.
\end{abstract}

Keywords: zeolite; growing lambs; calcium; magnesium; phosphorus; environmental pollution

\section{Introduction}

The highly intensive use of concentrate feeds to maximize the genetic potential efficiency of livestock, especially ruminants, has resulted in production and health problems that include but are not limited to decreased milk fat, reduced fiber digestibility, disturbed mineral absorption, as well as health risks related to an unbalanced acid-base concentration [1-3]. Hu and Murphy [4], Davis [1], and Iwaniuk and Erdman [5] investigated several strategies to reduce these concentrate feed-associated problems. According to these studies, the inclusion of dietary feed additives can be a best nutritional management practice serving to improve nutrient absorption, consequently reducing the environmental pollution that comes from animal waste. Dietary minerals for livestock animals are usually above the requirements, especially when using byproducts to reduce feeding costs, and this may have a negative effect on their absorption. The natural zeolite (clinoptilolite) and synthetic zeolites (e.g., zeolite A) may be appropriate feed additives, which can be used to improve the digestion and utilization of minerals.

Zeolites (clinoptilolites) are crystalline earth minerals with an aluminum (Al) and silicon $(\mathrm{Si})$ backbone, characterized by their capacity to reversibly lose and gain water and their affinity for positively charged ions $\left(\mathrm{K}^{+}, \mathrm{NH}_{4}{ }^{+}, \mathrm{Ca}^{2+}, \mathrm{Na}^{+}\right.$, and $\left.\mathrm{Mg}^{2+}\right)$, potentiated by their cation exchange capacity, $220 \mathrm{meq} / 100 \mathrm{~g}[6,7]$. Their ability to liberate ions in the rumen and eventually improve productivity has led to their approval for use as feed additives for ruminants by the European Commission at levels of no more than $2 \%$ of dry 
matter (DM) [8]. Clinoptilolite has been used and approved as a feed additive as it reduces mineral residuals in animal waste products.

A problem faced by farmers is a high Ca intake by lactating cows when fedhigh concentrate and roughages, with high levels of $\mathrm{Ca}$ intake. This required an a reduction or controlling the absorption of $\mathrm{Ca}$ from the intestinal tract to avoid the incidence of milk fever. Farmers seek an alternative means of $\mathrm{Ca}$ absorption reduction, since dairy cattle feed contain Ca levels beyond the level required, by using feed additives such as zeolite. Therefore, many studies have been looking for possible ways to reduce waste Ca levels by adding zeolite $\mathrm{A}$, due to its ability to bind dietary $\mathrm{Ca}$ and improve bioavailability by slowly releasing Ca. Previously, Ca concentrations were stabilized by including zeolite of up to $2 \%$ [9-12]; a negative impact on phosphorus (P) metabolism has been observed when the feed is supplemented above $3 \%$, as evidenced by cases of hypophosphatemia [9-13], which is a condition characterized by low phosphate levels in the blood, which may lead to seizures, coma, and osteoporosis.

A decrease in phosphate concentration was recorded when zeolite was added to rumen fluid in vitro, after acidification with hydrochloric acid [14]. Cook et al. [15] reported a temporal dissociation of zeolite at acidic $\mathrm{pH}$ into its constituents: $\mathrm{Al}$ silicate, $\mathrm{Al}$, and silicic acid. Inorganic $\mathrm{P}$ in the gastrointestinal tract (GIT) is bound by $\mathrm{Al}$ into a nonabsorbable form [16]. A decrease in the serum magnesium $(\mathrm{Mg})$ concentration of goats was reported by Schwaller et al. [17] when these were fed diets supplemented with zeolite at a concentration of $1.6 \%$ of DM. In the same study, zeolite supplementation increased the urinary concentration of $\mathrm{Ca}$ but led to a decrease in renal excretion of $\mathrm{P}$. There is limited information on the exact mechanism of the Ca-binding ability of zeolite, leaving the ultimate fate of zeolite in the GIT recourse for further study, and the levels of $\mathrm{Ca}, \mathrm{Mg}$, and $\mathrm{P}$ should also be explored in the context of dietary zeolite supplementation. In view of the above, this study was undertaken to evaluate the digestibility and concentrations of $\mathrm{Ca}, \mathrm{Mg}$, and $\mathrm{P}$ in tissue, rumen fluid, and blood of growing lambs fed a total mixed ration (TMR) diet supplemented with two different levels of natural zeolite (Clinoptilolite).

\section{Materials and Methods}

Ethical Approval

The study protocol, including the use of animals and procedures, was approved by the King Saud University's Animal Ethics Committee and was in accordance with the "Animal Welfare Act of Practice for the Care and Use of Animals for Scientific Purposes" guidelines.

\subsection{Animals and Management}

A total of twenty-four growing Naemi male lambs, (mean body weight (BW), $23 \pm 1.5 \mathrm{~kg}$; age, 3 months old) were randomly housed in individual pens for a trial period of seventyone days ( 15 days of adaptation and 56 days for experimentation and data and sample collection). The animals, purchased from the local livestock market and transported to the experimental farm of the Department of Animal Production, College of Food and Agricultural Sciences, King Saud University, were first quarantined (vaccinated against clostridial disease and treated for both internal and external parasites), weighed, and ear-tagged upon arrival at the farm. All lambs were fed a commercial TMR diet containing 1.95 Mcal ME $/ \mathrm{kg}$ and $13 \% \mathrm{CP} / \mathrm{kg}$ on a DM basis at a maintenance level of $2.5 \% \mathrm{BW}$ according to NRC [18]. The total mix diet consisted of a palm kernel meal (20\%), reflecting an inexpensive fiber source that is widely used, and which contains high levels of minerals, especially iron and phosphorus. The $\mathrm{Ca}, \mathrm{P}$ and $\mathrm{Mg}$ concentrations in the complete feed, as fed, were $9.47,2.27$ and $2.85 \mathrm{mg} / \mathrm{g}$, respectively. Feed was offered twice daily at morning and afternoon, whereas clean, cool, and portable water was offered ad libitum. Thereafter, lambs were randomly assigned to three dietary groups with eight male lambs in each. Lambs in the first group were fed a complete TMR diet (control); the second group was fed a TMR diet supplemented with zeolite at 1.0\% (0-1.0 mm particle size; TZ1), and the third group was fed a TMR diet supplemented with zeolite at $2 \%$ (0-1.0 mm particle size; TZ2). 
Data on feed intake and body weight were collected weekly and recorded. Blood samples were collected in the morning before feeding from the jugular vein into plain vacutainer tubes at day 1 and every 28 days up until the end of the trial and stored for analysis of serum values of $\mathrm{P}, \mathrm{Ca}$, and $\mathrm{Mg}$.

\subsection{Digestibility Trials and Slaughtering}

In the middle of the experiment, four lambs from each treatment group were moved into metabolic cages $(140 \mathrm{~cm} \times 100 \mathrm{~cm} \times 124 \mathrm{~cm})$ for an 8-day period (3 days for adaptation and 5 days for data collection) to be used in the digestibility trial. During this period, the weight of the feed offered, refused, and the weight of the feces and urine were measured daily at 08:00 a.m. Representative samples were collected and pooled ( $5 \%$ feed offered and refused and $20 \%$ of feces) for the subsample and then stored at $-20{ }^{\circ} \mathrm{C}$ for determination of apparent digestibility and subsequent analysis of trace minerals. At the end of the experiment, three lambs were randomly selected from each treatment group and slaughtered after being fasted for $16 \mathrm{~h}$, according to Islamic rules by severing the jugular vein and the carotid artery. Following extensive exsanguination, tissue samples-mainly liver, kidney and muscle tissue as well as rumen fluid-were collected.

\subsection{Mineral Analysis:}

Apparatus: A microwave-assisted digestion system (Anton Paar Australia) and Optima7000 DV-based inductively coupled plasma optical emission spectrometry (ICP-OES, PerkinElmer Corporation of USA) were used for the determination of $\mathrm{Ca}, \mathrm{P}$, and $\mathrm{Mg}$ concentrations in the blood and tissues samples collected.

\subsubsection{Operational Parameters of the Microwave Digestion:}

Power: $1200 \mathrm{~W}$, Socratic ramp at $260{ }^{\circ} \mathrm{C}$ for $15 \mathrm{~min}$, hold for $15 \mathrm{~min}$; power: $300 \mathrm{~W}$, ramp: $160{ }^{\circ} \mathrm{C}$ for $5 \mathrm{~min}$, hold for $12 \mathrm{~min}$ at a pressure of 40 bar. Working conditions of ICP-OES: RF Power: $1.3 \mathrm{~kW}$; auxiliary gas flow rate $(\mathrm{Ar}): 0.5 \mathrm{~L} / \mathrm{min}$; cooling gas flow (Ar): 15.0 L/min; carrier gas flow (Ar): $0.75 \mathrm{~L} / \mathrm{min}$.

\subsubsection{Procedure:}

Approximately $0.50 \mathrm{~g}$ of tissue sample was weighed into a polytetrafluoroethylene (PTFE) bomb, and $3 \mathrm{~mL}$ of concentrated $\mathrm{HNO}_{3}, 1.0 \mathrm{~mL}$ concentrated $\mathrm{HCl}$, and $2.5 \mathrm{~mL}$ of $30 \% \mathrm{H}_{2} \mathrm{O}_{2}$ were added. Sixteen parallel samples were digested simultaneously using the optimized microwave digestion system mentioned above. When the digestion program was complete, a twenty-minute ventilation step (no microwave power) cooled the vessels by reducing the pressure inside to ambient values. After digestion, the solution was transferred into a volumetric flask and made up to $50 \mathrm{~mL}$ with de-ionized water. Further dilutions were prepared for the analysis to fall within the dynamic range of the calibration curve. Blank and quality control sample solutions were prepared in the same way as the samples. Concentrations of mineral elements in the samples were determined by ICP-OES against concentration series of external standards used for calibration curve construction. Calibration curves were constructed with a regression coefficient $\left(R^{2}\right)$ greater than 0.99 .

\subsection{Statistical Analysis:}

Data generated from this study were analyzed in the setting of a completely randomized design, using the generalized linear model procedure of SAS [19] and presented as means $( \pm$ SEM). The model that was used to analyze the data is as follows:

$$
y i j=\mu+\tau i+\beta j+\varepsilon i j,
$$

where $y i j=$ an observation of dependent variables for $\mathrm{Ca}, \mathrm{P}$, and $\mathrm{Mg}$ concentrations in different tissues; $\mu=$ the overall mean; $\tau i=$ the effect of zeolite supplementation at specified levels $(0 \%, 1 \%$, and $2 \%$, respectively). $\beta \mathrm{j}=$ the lambs effect of block $\mathrm{j}$; and $\varepsilon \mathrm{ij}=$ residual error. The Pearson correlation test was performed to test differences in the concentration 
of minerals in different tissues, serum, and rumen fluid since the data were normally distributed. Differences between means were tested using least significant differences at a probability $(p)$ level $<0.05$.

\section{Results and Discussion}

\subsection{Performance and Nutrient Digestibility}

The mean values of the growth, feed conversion ratio (FCR) and digestibility coefficient and absorption of minerals records of the lambs are listed in Table 1. Significant $(p<0.05)$ differences were observed in the BW of lambs fed a complete diet with zeolite supplementation. The control group (C) shared characteristics similar to those of the lambs treated with $1 \%$ zeolite (T1); the T1 group showed a non-significant increase in BW $(11.91 \mathrm{~kg})$ compared with the control group $(10.72 \mathrm{~kg})$. Meanwhile, lambs fed a complete diet supplemented with $2 \%$ zeolite exhibited significantly higher mean BWs $(13.42 \mathrm{~kg}$; $p<0.05)$. Treated lambs had significantly different FCR compared with the control lambs $(p<0.05)$, though the difference in the levels of zeolite showed no significant difference. The digestibility coefficients of various minerals are also presented in Table 1. Phosphorus digestibility was significantly $(p<0.05)$ increased with the addition of zeolite. Although an increase was observed with zeolite addition, the digestibility of $\mathrm{Ca}$ and $\mathrm{Mg}$ remained unaffected $(p>0.05)$. Introduction of zeolite at $1 \%$ showed greater digestibility of the minerals under investigation. In contrast to the results presented herein, zeolite addition to lamb diets [20] and feedlot steer diets [21] was reported to have no impact on FCR. Moreover, several studies have showed that feed intake increases with zeolite addition [22-25], at the same time improving FCR [23,26-28].

Table 1. Performance and digestibility of calcium (Ca), phosphorous (P), and magnesium (Mg) of Naemi lambs as influenced by dietary zeolite supplementation.

\begin{tabular}{|c|c|c|c|c|c|}
\hline Parameters & $\mathrm{C}$ & T1 & T2 & SEM & $p$ Value \\
\hline $\mathrm{BW}, \mathrm{kg}$ & $10.72^{\mathrm{a}}$ & $11.91^{\mathrm{a}}$ & $13.42^{b}$ & 1.2 & $<0.017$ \\
\hline FCR & $4.12^{\mathrm{b}}$ & $3.65^{\mathrm{a}}$ & $3.45^{\mathrm{a}}$ & 0.43 & $<0.05$ \\
\hline \multicolumn{6}{|c|}{ Digestibility Coefficients } \\
\hline DFI, $g$ & 1582.5 & 1717.5 & 1722 & 47 & 0.35 \\
\hline Fecal, g & 872.5 & 775.5 & 782.1 & 113 & 0.81 \\
\hline Ca digestibility, $\%$ & 79.31 & 82.08 & 80.30 & 4.12 & 0.68 \\
\hline $\mathrm{P}$ digestibility, \% & $86.60^{\mathrm{a}}$ & $91.23^{b}$ & $90.9^{b}$ & 3.87 & 0.04 \\
\hline Mg digestibility, $\%$ & 88.33 & 90.61 & 90.11 & 2.54 & 0.45 \\
\hline
\end{tabular}

${ }_{\mathrm{ab}}$ Means with same superscript letters do not differ $(p>0.05)$ significantly. $\mathrm{C}=$ control group; $\mathrm{T} 1=$ group of lambs receiving a diet supplemented with $1 \%$ zeolite; $\mathrm{T} 2$ = group of lambs receiving a diet supplemented with $2 \%$ zeolite; SEM = standard error of the mean; BW = body weight; FCR = feed conversion ratio; DFI = daily feed intake.

\subsection{Intestinal Metabolism of Calcium, Magnesium and Phosphorus}

Data on tissue mineral metabolism are presented in Table 2. Non-significant $(p>0.05)$ differences were observed in the results obtained for $\mathrm{Ca}, \mathrm{Mg}$, and $\mathrm{P}$ in liver tissue, regardless of zeolite supplementation. However, the addition of zeolite resulted in a decrease $(p<0.05)$ in the Ca concentration in the kidney and muscle tissue, though the Ca concentration at $2 \%$ (123.13 and $48.49 \mu \mathrm{g} / \mathrm{g}$ wet weight (ww), respectively) was significantly $(p<0.05)$ higher than supplementation at $1 \%(120.13$ and $45.66 \mu \mathrm{g} / \mathrm{g} w \mathrm{w}$, respectively) for kidney and muscle tissue. As in the liver tissue, non-significant $(P>0.05)$ differences were observed in the kidney and muscle tissue of lambs receiving a zeolite-supplemented diet with regard to $\mathrm{P}$ and $\mathrm{Mg}$ concentration. Furthermore, a strong negative correlation $(\mathrm{r}=-0.99$, Table 3$)$ was observed between the calcium concentration in the liver and that in kidney tissue for zeolite added at a supplementation rate of $2 \%$. We also observed that the liver Ca level in lambs receiving $1 \%$ zeolite was positively correlated with the Ca concentration in muscle tissue in lambs receiving $0 \%$ and $1 \%$ zeolite supplementation. Differences in tissue mineralization of $\mathrm{Mg}$ and $\mathrm{P}$ were either insignificant or had no explainable relationships 
across the treatments. A positive correlation between liver and renal concentrations of $\mathrm{P}$ was observed in animals receiving the $2 \%$ zeolite supplementation (Table 4 ). At the same time, a negative correlation was observed in ruminal $\mathrm{P}$ with zeolite treatment at $2 \%$ and the P concentration in the liver of lambs receiving no zeolite $(0 \%)$. Similarly, a negative correlation was observed for P levels in the rumen and kidney at $1 \%$ zeolite supplementation. The Mg concentrations in the liver, kidney, and muscle tissue were strongly positively correlated (Table 5).

Table 2. Mineralization in liver, kidney, and muscle tissue ( $\mu \mathrm{g} / \mathrm{g} \mathrm{ww}$ ) in Naemi lambs fed a complete diet with (T1 and T2) and without (C) zeolite supplementation.

\begin{tabular}{ccccccc}
\hline Tissue & Mineral & $\mathbf{C}$ & T1 & T2 & $p$ Value & SEM \\
\hline \multirow{2}{*}{ Liver } & $\mathrm{Ca}$ & 79.53 & 93.51 & 82.13 & 0.65 & \pm 5.87 \\
& $\mathrm{P}$ & 79.53 & 93.51 & 82.13 & 0.12 & \pm 5.87 \\
& $\mathrm{Mg}$ & 222.48 & 229.36 & 228.43 & 0.78 & \pm 3.86 \\
\multirow{5}{*}{ Kidney } & $\mathrm{Ca}$ & $168.97^{\mathrm{b}}$ & $120.13^{\mathrm{a}}$ & $123.13^{\mathrm{ab}}$ & 0.37 & \pm 9.63 \\
& $\mathrm{P}$ & 3006 & 3026.79 & 3377.39 & 0.31 & \pm 105.65 \\
& $\mathrm{Mg}$ & 216 & 216.55 & 268.17 & 0.25 & \pm 14.16 \\
Muscle & $\mathrm{Ca}$ & $56.72^{\mathrm{b}}$ & $45.66^{\mathrm{a}}$ & $48.49^{\mathrm{a}}$ & 0.09 & \pm 2.25 \\
& $\mathrm{P}$ & 2083 & 3123.8 & 2089 & 0.63 & \pm 16.83 \\
& $\mathrm{Mg}$ & 271.86 & 276.68 & 271.26 & 0.80 & \pm 3.25 \\
\hline
\end{tabular}

$\overline{\mathrm{ab}}$ Means with same superscript letters do not differ $p(>0.05)$ significantly. $\mathrm{C}=$ control group; T1 = group of lambs receiving a diet supplemented with $1 \%$ zeolite; $\mathrm{T} 2$ = group of lambs receiving a diet supplemented with $2 \%$ zeolite; SEM = standard error of the mean; $\mathrm{Ca}=$ calcium; $\mathrm{P}=$ phosphorous; $\mathrm{Mg}=$ magnesium.

Table 3. The correlation matrix of calcium (Ca) concentration between tissues, rumen fluid and serum of growing lambs supplemented with zeolite.

\begin{tabular}{|c|c|c|c|c|c|c|c|c|c|c|c|c|c|c|c|c|}
\hline & Variables & 1 & 2 & 3 & 4 & 5 & 6 & 7 & 8 & 9 & 10 & 11 & 12 & 13 & 14 & 15 \\
\hline 1 & LivCaC & 1 & & & & & & & & & & & & & & \\
\hline 2 & LivCaT1 & 0.36 & 1 & & & & & & & & & & & & & \\
\hline 3 & LivCaT2 & -0.60 & 0.53 & 1 & & & & & & & & & & & & \\
\hline 4 & $\mathrm{KiCaC}$ & 0.75 & -0.34 & -0.98 & 1 & & & & & & & & & & & \\
\hline 5 & KiCaT1 & -0.45 & 0.67 & 0.98 & 0.93 & 1 & & & & & & & & & & \\
\hline 6 & KiCaT2 & 0.59 & -0.54 & $-0.99 *$ & 0.97 & -0.98 & 1 & & & & & & & & & \\
\hline 7 & $\mathrm{RuCaC}$ & 0.98 & 0.56 & -0.41 & 0.58 & -0.24 & 0.40 & 1 & & & & & & & & \\
\hline 8 & RuCaT1 & -0.62 & -0.96 & -0.25 & 0.05 & -0.41 & 0.27 & -0.78 & 1 & & & & & & & \\
\hline 9 & RuCaT2 & 0.77 & 0.87 & 0.05 & 0.15 & 0.22 & -0.06 & 0.89 & -0.98 & 1 & & & & & & \\
\hline 10 & $\mathrm{MeCaC}$ & 0.32 & 0.99 * & 0.56 & -0.38 & 0.70 & -0.58 & 0.52 & -0.94 & 0.85 & 1 & & & & & \\
\hline 11 & MeCaT1 & 0.25 & 0.99 * & 0.63 & -0.45 & 0.75 & -0.64 & 0.45 & -0.91 & 0.81 & $0.99 *$ & 1 & & & & \\
\hline 12 & MeCaT2 & -0.79 & 0.28 & 0.96 & -0.99 & 0.90 & -0.96 & -0.64 & 0.02 & -0.22 & 0.32 & 0.40 & 1 & & & \\
\hline 13 & $\mathrm{SeCaC}$ & -0.98 & -0.16 & 0.76 & -0.87 & 0.62 & -0.75 & -0.91 & 0.44 & -0.62 & -0.11 & -0.03 & 0.90 & 1 & & \\
\hline 14 & SeCaT1 & -0.79 & 0.28 & 0.96 & -0.99 & 0.90 & -0.96 & -0.64 & 0.01 & -0.22 & 0.32 & 0.40 & $0.99 *$ & 0.90 & 1 & \\
\hline 15 & SeCaT2 & -0.99 & -0.47 & 0.51 & -0.67 & 0.34 & -0.49 & $-0.99 *$ & 0.71 & -0.84 & -0.43 & -0.35 & 0.72 & 0.95 & 0.72 & 1 \\
\hline
\end{tabular}

LivCaC: liver calcium control group; LivCaT1: liver calcium level 1 of zeolite; LivCaT2: liver calcium level 2 of zeolite; KiCaC: kidneys calcium control; KiCaT1: kidneys calcium level 1 of zeolite; KiCaT2: kidneys calcium level 2 of zeolite. RuCaC: rumen calcium control group; RuCaT1: rumen calcium level 1 of zeolite; RuCaT2: rumen calcium level 2 of zeolite. MeCaC: meat calcium control group; MeCaT1: meat calcium level 1 of zeolite; MeCaT2: meat calcium level 2 of zeolite. SeCaC: serum calcium control group; SeCaT1: serum calcium level 1 of zeolite; SeCaT2: serum calcium level 2 of zeolite. ${ }^{*} p<0.05 .{ }^{* *} p<0.01$.

\subsection{Ruminal Metabolism of Calcium, Phosphorus, and Magnesium}

In the current study, the ruminal levels of $\mathrm{Ca}, \mathrm{P}$, and $\mathrm{Mg}$ remained unaffected $(p>0.05)$ by the addition of zeolite. Compared with the control group (C), Ca and P levels were nonsignificantly higher in the T1 group and non-significantly lower in the T2 group (Figure 1). The P:Ca ratio remained similar across the groups. The $\mathrm{Mg}$ concentration in the rumen fluid declined with increasing levels of zeolite, though this decrease appeared non-significant $(p>0.05)$. In an in vitro study, Thilsing et al. [14] showed a zeolite-induced reduction in $\mathrm{Mg}$ in supernatants of rumen fluid. They also showed that zeolite is not Ca-specific in that it additionally ties $\mathrm{P}$ and, although to a lesser degree, $\mathrm{Mg}$ [9]. 
Table 4. The correlation matrix of phosphorus $(\mathrm{P})$ concentration between tissues, rumen fluid and serum of growing lambs supplemented with zeolite.

\begin{tabular}{|c|c|c|c|c|c|c|c|c|c|c|c|c|c|c|c|c|}
\hline & Variables & 1 & 2 & 3 & 4 & 5 & 6 & 7 & 8 & 9 & 10 & 11 & 12 & 13 & 14 & 15 \\
\hline 1 & LivPC & 1 & & & & & & & & & & & & & & \\
\hline 2 & LivPT1 & 0.72 & 1 & & & & & & & & & & & & & \\
\hline 3 & LivPT2 & $0.99 *$ & 0.81 & 1 & & & & & & & & & & & & \\
\hline 4 & KiPC & -0.66 & -0.99 & -0.75 & 1 & & & & & & & & & & & \\
\hline 5 & KiPT1 & 0.50 & -0.24 & 0.38 & 0.32 & 1 & & & & & & & & & & \\
\hline 6 & KiPT2 & $0.99 *$ & 0.77 & 0.99 * & 0.72 & 0.43 & 1 & & & & & & & & & \\
\hline 7 & RuPC & -0.96 & -0.88 & -0.98 * & 0.84 & 0.24 & -0.98 & 1 & & & & & & & & \\
\hline 8 & RuPT1 & -0.40 & 0.35 & -0.27 & -0.43 & $-0.99 *$ & -0.32 & 0.13 & 1 & & & & & & & \\
\hline 9 & RuPT2 & -0.99 * & -0.79 & $-0.99 *$ & -0.72 & -0.41 & -0.99 * & 0.98 & 0.30 & 1 & & & & & & \\
\hline 10 & MePC & 0.48 & 0.95 & 0.59 & -0.98 & -0.52 & 0.55 & -0.70 & 0.62 & -0.56 & 1 & & & & & \\
\hline 11 & MePT1 & -0.26 & 0.48 & -0.13 & -0.56 & -0.97 & -0.18 & -0.02 & 0.98 & 0.16 & 0.73 & 1 & & & & \\
\hline 12 & MePT2 & $-0.99 *$ & -0.77 & $-0.99 *$ & -0.72 & -0.43 & $-1^{* *}$ & 0.98 & 0.32 & $0.99 *$ & -0.55 & 0.18 & 1 & & & \\
\hline 13 & SePC & 0.99 & 0.60 & 0.96 & -0.53 & 0.64 & 0.97 & -0.90 & -0.54 & -0.97 & 0.33 & -0.41 & -0.97 & 1 & & \\
\hline 14 & SePT1 & 0.74 & 0.07 & 0.65 & 0.01 & 0.95 & 0.69 & -0.53 & -0.91 & -0.67 & -0.23 & -0.84 & -0.69 & 0.41 & 1 & \\
\hline 15 & SePT2 & 0.99 * & 0.72 & 0.99 * & -0.65 & 0.51 & 0.99 * & -0.96 & -0.40 & -0.99 * & 0.47 & -0.26 & 0.99 * & 0.87 & 0.74 & 1 \\
\hline
\end{tabular}

LivPC: liver phosphorus control group; LivPT1: liver phosphorus level 1 of zeolite; LivPT2: liver phosphorus level 2 of zeolite; KiPC: kidneys phosphorus control; KiPT1: kidneys phosphorus level 1 of zeolite; KiPT2: zinc level 2 of zeolite. RuPC: rumen phosphorus control group; RuPT1: rumen phosphorus level 1 of zeolite; RuPT2: rumen phosphorus level 2 of zeolite. MePC: meat phosphorus control group; MePT1: meat phosphorus level 1 of zeolite; MePT2: meat phosphorus level 2 of zeolite. SePC: serum phosphorus control group; SePT1: serum phosphorus level 1 of zeolite; SePT2: serum phosphorus level 2 of zeolite. ${ }^{*} p<0.05 .{ }^{* *} p<0.01$.

Table 5. The correlation matrix of magnesium $(\mathrm{Mg})$ concentration between tissues, rumen fluid and serum of growing lambs supplemented with zeolite.

\begin{tabular}{|c|c|c|c|c|c|c|c|c|c|c|c|c|c|c|c|c|}
\hline & Variables & 1 & 2 & 3 & 4 & 5 & 6 & 7 & 8 & 9 & 10 & 11 & 12 & 13 & 14 & 15 \\
\hline 1 & LivMgC & 1 & & & & & & & & & & & & & & \\
\hline 2 & LivMgT1 & 0.60 & 1 & & & & & & & & & & & & & \\
\hline 3 & LivMgT2 & -0.42 & 0.47 & 1 & & & & & & & & & & & & \\
\hline 4 & $\mathrm{KiMgC}$ & $1 * *$ & 0.60 & -0.42 & 1 & & & & & & & & & & & \\
\hline 5 & KiMgT1 & -0.86 & -0.11 & 0.82 & -0.85 & 1 & & & & & & & & & & \\
\hline 6 & KiMgT2 & -0.59 & 0.29 & 0.98 & 0.59 & 0.91 & 1 & & & & & & & & & \\
\hline 7 & $\mathrm{RuMgC}$ & 0.08 & -0.75 & -0.94 & -0.08 & -0.58 & -0.85 & 1 & & & & & & & & \\
\hline 8 & RuMgT1 & 0.90 & 0.20 & -0.77 & -0.9 & -0.99 * & -0.88 & 0.51 & 1 & & & & & & & \\
\hline 9 & RuMgT2 & -0.25 & -0.93 & -0.77 & -0.25 & -0.27 & -0.63 & 0.94 & 0.19 & 1 & & & & & & \\
\hline 10 & $\mathrm{MeMgC}$ & 0.69 & $0.99 *$ & 0.37 & -0.68 & -0.21 & 0.18 & -0.67 & 0.31 & -0.88 & 1 & & & & & \\
\hline 11 & MeMgT1 & -0.45 & -0.98 & -0.62 & -0.44 & -0.07 & -0.46 & 0.85 & -0.02 & 0.98 & -0.96 & 1 & & & & \\
\hline 12 & MeMgT2 & -0.99 * & -0.61 & 0.41 & -0.99 & 0.85 & 0.58 & -0.07 & -0.90 & 0.27 & -0.70 & 0.46 & 1 & & & \\
\hline 13 & SeMgC & 0.75 & 0.98 & 0.29 & -0.74 & -0.3 & 0.10 & -0.60 & 0.38 & -0.83 & $0.99 *$ & -0.93 & -0.75 & 1 & & \\
\hline 14 & SeMgT1 & -0.88 & -0.91 & -0.07 & -0.87 & 0.5 & 0.13 & 0.40 & -0.58 & 0.69 & -0.95 & 0.82 & 0.88 & -0.97 & 1 & \\
\hline 15 & SeMgT2 & 0.79 & 0.97 & 0.23 & -0.78 & -0.35 & 0.03 & -0.55 & 0.44 & -0.80 & $0.98^{*}$ & -0.90 & -0.79 & $0.99 *$ & -0.99 & 1 \\
\hline
\end{tabular}

LivPC: liver magnesium control group; LivPT1: liver magnesium level 1 of zeolite; LivPT2: liver magnesium 1 level 2 of zeolite; KiPC: kidneys magnesium control; KiPT1: kidneys magnesium level 1 of zeolite; KiPT2: kidneys magnesium level 2 of zeolite. RuPC: rumen magnesium control group; RuPT1: rumen magnesium level 1 of zeolite; RuPT2: rumen magnesium level 2 of zeolite. MePC: meat magnesium control group; MePT1: meat magnesium level 1 of zeolite; MePT2: meat magnesium level 2 of zeolite. SePC: serum magnesium control group; SePT1: serum magnesium level 1 of zeolite; SePT2: serum magnesium level 2 of zeolite. ${ }^{*} p<0.05 .{ }^{* *} p<0.01$.



Figure 1. Ruminal fluid concentration of calcium (Ca), magnesium (Mg), and phosphorus (P) as influenced by dietary level of zeolite supplementation. 


\subsection{Mineral Concentration in Serum}

No significant $(p>0.05)$ differences were observed in $\mathrm{Ca}, \mathrm{P}$, or $\mathrm{Mg}$ concentrations in serum, irrespective of zeolite inclusion (Figure 2). The concentrations of $\mathrm{Ca}, \mathrm{P}$, and $\mathrm{Mg}$ were numerically lower in the blood samples from lambs fed diets supplemented with $2 \%$ zeolite. The use of zeolite as a calcium binder during the dry period of dairy cows is a new strategy for preventing parturient hypocalcemia [12]. In the current study, the serum concentrations of all three minerals were lowest in animals receiving a diet supplemented with $2 \%$ zeolite, which is in agreement with the findings of Toprak et al. [28] who studied lambs fed a diet supplemented with $2 \%$ and $3 \%$ zeolite. The reductions observed in the present study could be linked to the formation of complexes through zeolite breakdown in the GIT, resulting in the release of insoluble materials downstream, while Ca is released in the abomasum and available in the intestine. The observation of a reduced mineral concentration, though not of significant importance, is in line with some in-vivo experiments, where zeolite administration significantly reduced serum $P$ concentrations $[29,30]$. Other factors, such as $\mathrm{Ca}$ acetate or carbonates of sevelamer and lanthanum, are phosphate binders used in kidney therapeutics in human medicine and reported for both urinary and serum $\mathrm{P}$ reduction [31]. In several experiments with lambs [32,33], goats [34], and cattle [35,36], diets with low $\mathrm{P}$ concentrations led to an increased Ca concentration in the blood, contradicting the findings of the present study. The complete diet contained $1.7 \% \mathrm{Ca}$ and $0.42 \% \mathrm{P}$, but the serum concentration of the latter appeared to exceed that of $\mathrm{Ca}$, allowing the inference that calcium absorption was relatively ineffective. The fact that $\mathrm{Mg}$ was reduced, although not significantly so, is in accordance with results reported by Enemark et al. [29], in which treated groups showed significantly lower serum Mg concentrations. From the above findings regarding the $\mathrm{Ca}, \mathrm{P}$ and $\mathrm{Mg}$ digestion, absorption and utilization, it is evident that zeolite can play an important role in mineral metabolism and bioavailability which is clearly reported for P. So, further research is recommended that uses minerals isotopes and fistulated ruminat animals to deeply investigate the positive or negative effect of zeolite supplementation and proper levels.

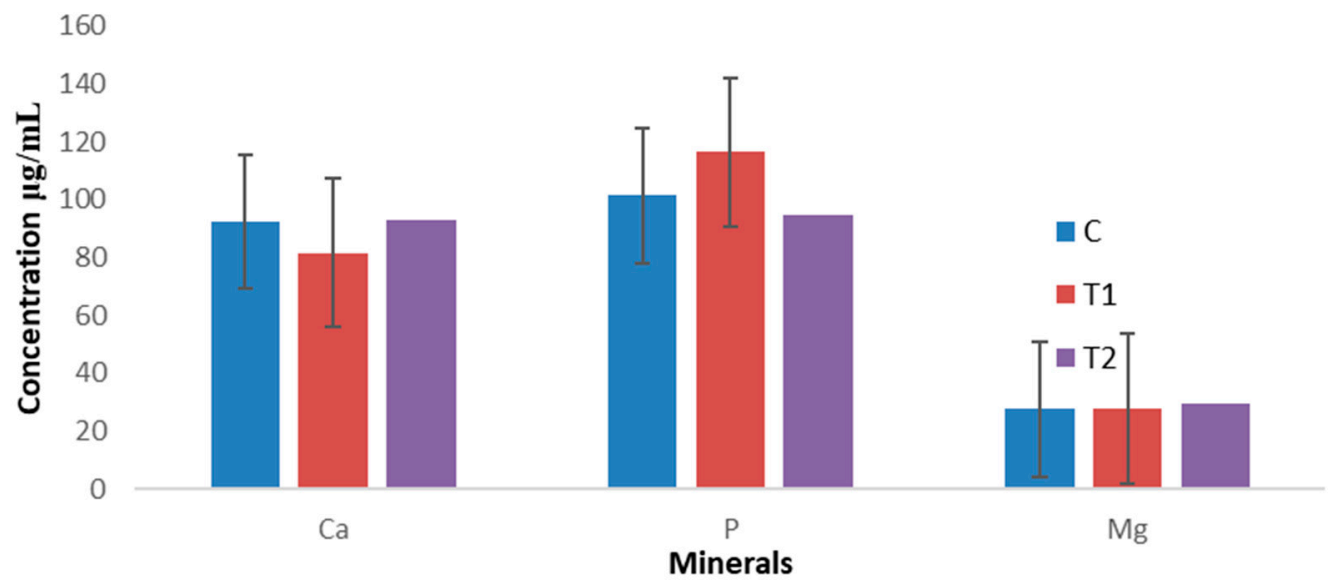

Figure 2. Serum concentration of calcium (Ca), magnesium $(\mathrm{Mg})$, and phosphorus $(\mathrm{P})$ as influenced by dietary level of zeolite supplementation.

\section{Conclusions}

In conclusion, maintaining mineral homeostasis is important for various production and health functions of farm animals. This study demonstrated that the addition of zeolite at $2 \%$ moderately increased the performance of lambs. The homeostasis was maintained in the mineral $(\mathrm{Ca}, \mathrm{Mg}$, and $\mathrm{P})$ concentration in blood, and at the same time, the renal and liver functions were kept intact. Problems with phosphate absorption could be solved by adding zeolite $(2 \%)$, which improves uptake efficiency and reduces environmental pollution. 
Author Contributions: M.M.A. (Mutassim M. Abdelrahman) and I.A. designed and outlined the experiment, wrote the manuscript, and generally followed up on the feeding trial. R.A. followed up the data collection and statistical analysis with data presentation and reviewed the article; M.M.A. (Mohsen M. Alobre), Y.A.A. and H.A. executed the experimental work, data collection and samples analysis in the lab. All authors have read and agreed to the published version of the manuscript.

Funding: This research received no external funding, but University internal funding was provided by Deanship of Scientific Research at King Saud University for funding this work through research group RG-1441-408.

Institutional Review Board Statement: The study protocol, including the use of animals and procedures, was approved by the King Saud University's Animal Ethics Committee and was in accordance with the "Animal Welfare Act of Practice for the Care and Use of Animals for Scientific Purposes" guidelines.

Informed Consent Statement: Not applicable.

Data Availability Statement: The data of this manuscript is available upon request.

Acknowledgments: The authors would like to extend their sincere appreciation to the Deanship of Scientific Research at King Saud University for funding this work through research group RG-1441-408.

Conflicts of Interest: The authors declare no conflict of interest.

\section{References}

1. Davis, C.L. The use of buffers in the rations of lactating dairy cows. In Regulation of Acid-Base Balance; Hale, W.H., Meinhardt, P., Eds.; Church and Dwight Co. Inc.: Piscataway, NJ, USA, 1979.

2. Muller, L.D.; Kilmer, L.H. Sodium Bicarbonate in Dairy Nutrition; National Feed Ingredients Association: West Des Moines, IA, USA, 1979; pp. 34-64.

3. Snyder, T.J.; Rogers, J.A.; Muller, L.D. Effects of 1.2\% sodium bicarbonate with two ratios of corn silage:grain on milk production, rumen fermentation and nutrient digestion by lactating cows. J. Dairy Sci. 1983, 66, 1290-1297. [CrossRef]

4. Hu, W.; Murphy, M.R. Statistical evaluation of early- and mid-lactation dairy cow responses to dietary sodium bicarbonate addition. Anim. Feed. Sci. Technol. 2005, 119, 43-54. [CrossRef]

5. Iwaniuk, M.E.; Erdman, R.A. Intake, milk production, ruminal, and feed efficiency responses to dietary cation-anion difference by lactating dairy cows. J. Dairy Sci. 2015, 98, 8973-8985. [CrossRef] [PubMed]

6. Bosi, P.; Creston, D.; Casini, L. Production performance of dairy cows after the dietary addition of clinoptilolite. Ital. J. Anim. Sci. 2002, 1, 187-195. [CrossRef]

7. Fillippidis, F.A.; Godelitsas, A.; Charistos, D.; Misaelides, P.; Kassoli-Fournaraki, A. The chemical behavior of natural zeolites in aqueous environments: Interactions between low-silica zeolites and $1 \mathrm{M} \mathrm{NaCl}$ solutions of different initial pH-values. Appl. Clay Sci. 1996, 11, 199-209. [CrossRef]

8. European Commission Regulation. European Commission Regulation No. 1810/2005 of 4 November 2005 concerning a new authorization for 10 years of an additive in feeding stuffs, the permanent authorization of certain additives in feeding stuffs and the provisional authorization of new uses of certain additives already authorized in feeding stuffs. Off. J. Eur. Union 2005, $291,1-7$.

9. Thilsing-Hansen, T.; Jørgensen, R.J.; Enemark, J.M.; Larsen, T. The effect of zeolite A supplementation in the dry period on periparturient calcium, phosphorus, and magnesium homeostasis. J. Dairy Sci. 2002, 85, 1855-1862. [CrossRef]

10. Thilsing-Hansen, T.; Jørgensen, R.J.; Enemark, J.M.; Zelvyte, R.; Sederevicius, A. The effect of zeolite A supplementation in the dry period on blood mineral status around calving. Acta Vet. Scand. 2003, 97, 87-95.

11. Pallesen, A.; Pallesen, F.; Jørgensen, R.J.; Thilsing, T. Effect of pre-calving zeolite, magnesium and phosphorus supplementation on periparturient serum mineral concentrations. Vet. J. 2008, 175, 234-239. [CrossRef]

12. Grabherr, H.; Spolders, M.; Lebzien, P.; Hüther, L.; Flachowsky, G.; Fürll, M.; Grün, M. Effect of zeolite A on rumen fermentation and phosphorus metabolism in dairy cows. Arch. Anim. Nutr. 2009, 63, 321-336. [CrossRef]

13. Grabherr, H.; Spolders, M.; Flachowsky, G.; Fürll, M. Einfluss von Zeolith A auf die Futteraufnahme von trockenstehenden Milchkühen, auf den Mengen- und Spurenelementstoffwechsel im peripartalen Zeitraum sowie auf die Milchleistung in der folgenden Laktation. Berl. Münch. Tierärztl. Wochenschr. 2008, 12, 41-52.

14. Thilsing-Hansen, T.; Jørgensen, R.J. Hot topic: Prevention of parturient paresis and subclinical hypocalcemia in dairy cows by zeolite A administration in the dry period. J. Dairy Sci. 2001, 84, 691-693. [CrossRef]

15. Cook, T.E.; Cilley, W.A.; Savitsky, A.C.; Wiers, B.H. Zeolite A hydrolysis and degradation. Environ. Sci. Technol. 1982, 16, 344-350. [CrossRef]

16. Allen, V.G. Influence of dietary aluminum on nutrient utilization in ruminants. J. Anim. Sci. 1984, 59, 836-844. [CrossRef]

17. Schwaller, D.; Wilkens, M.R.; Liesegang, A. Zeolite A effect on calcium homeostasis in growing goats. J. Anim. Sci. 2016, 94, 1576-1586. [CrossRef] 
18. NRC (National Research Council). Nutrient Requirements of Small Ruminants: Sheep, Goats Cervids and New World Camelids; National Academy Press: Washington, DC, USA, 2007.

19. SAS Institute. SAS User's Guide. Statistics, 8th ed.; SAS Institute Inc.: Cary, NC, USA, 2003.

20. Ochodnicky, D.; Huncik, M.; Bajdal, K. Effect of Zeolite Supplement with Lamb Fattening; FAO: Rome, Italy, 1986.

21. McCollum, F.T.; Galyean, M.L. Effects of clinoptilolite on rumen fermentation, digestion and feedlot performance in beef steers fed high concentrate diets. J. Anim. Sci. 1983, 56, 517-524. [CrossRef]

22. Sanders, K.J.; Richardson, C.R.; Harper, S. Effects of Zeolites on Performance of Feedlot Cattle; Texas Technical University, Animal Science: Lubbock, TX, USA, 1997; Available online: http://www.zeolite-products.com/ktml2/files/uploads/Effects\%20of\%20 zeolites \%20on\%20performance \%20of\%20feedlot\%20cattle.pdf (accessed on 1 February 2021).

23. Koknaroglu, H.; Toker, M.T.; Bozkurt, Y. Effect of zeolite and initial weight on feedlot performance of Brown Swiss cattle. Asian. J. Anim. Vet. Adv. 2006, 1, 49-54. [CrossRef]

24. Câmara, L.R.A.; Valadares Filho, S.C.; Leão, M.I.; Valadares, R.F.D.; Dias, M.; Gomide, A.P.C.; Barros, A.C.W.; Nascimento, V.A.; Ferreira, D.J.; Faé, J.T.; et al. Zeólita na dieta de bovinos de corte. Arq. Bras. Med. Vet. Zootec. 2012, 64, 631-639. [CrossRef]

25. Stojkovic., J.; Ilic, Z.; Ciric, S.; Ristanovic, B.; Petrovic, M.P.; Caro-Petrovic, V.; Kurcubic, V. Efficiency of zeolite basis preparation in fattening lambs diet. Biotech. Anim. Husb. 2012, 28, 545-552. [CrossRef]

26. Nestorov, N. Possible applications of natural zeolites in animal husbandry. In Zeo agriculture: Use of Natural Zeolite in Agriculture and Aquaculture; International Committee on Natural Zeolites: Boulder, CO, USA, 1984; pp. 167-174.

27. Nowar, M.S.; Al-Shawabkeh, K.; Khoury, H.N. Effect of feeding farm animals with Jordanian clay deposits containing montmorillonite: 1. Effect on fattening lambs performance, with special reference to blood hematology, liver and kidney functions, and parasitological and serological examinations. Zagaz. Agric. Res. 1993, 20, 651-667.

28. Toprak, N.N.; Yılmaz, A.; Öztürk, E.; Yigit, O.; Cedden, F. Effect of micronized zeolite addition to lamb concentrate feeds on growth performance and some blood chemistry and metabolites. S. Afr. J. Anim. Sci. 2016, 46, 313-320.

29. Enemark, J.M.; Frandsen, A.M.; Thilsing-Hansen, T.; Jørgensen, R.J. Aspects of physiological effects of sodium zeolite, A supplementation in dry, non-pregnant dairy cows fed grass silage. Acta Vet. Scand. Suppl. 2003, 97, 97-117. [PubMed]

30. Kraljević Pavelić, S.; Simović Medica, J.; Gumbarević, D.; Filošević, A.; Pržulj, N.; Pavelić, K. Critical Review on Zeolite Clinoptilolite Safety and Medical Applications in vivo. Front. Pharmacol. 2018, 9, 1-15. [CrossRef] [PubMed]

31. Block, G.A.; Wheeler, D.C.; Persky, M.S.; Kestenbaum, B.; Ketteler, M.; Spiegel, D.M.; Allison, M.A.; Asplin, J.; Smits, G.; Hoofnagle, A.N.; et al. Effects of phosphate binders in moderate CKD. J. Am. Soc. Nephrol. 2012, 23, 1407-1415. [CrossRef]

32. Maunder, E.M.; Pillay, A.V.; Care, A.D. Hypophosphataemia and vitamin D metabolism in sheep. Q. J. Exp. Physiol. 1986, 71, 391-399. [CrossRef]

33. Scott, D.; Loveridge, N.; Nicodemo, L.; Buchan, W.; Milne, J.; Duncan, A.; Nicol, P.; Robins, S.P. Effect of diets varying in nitrogen or phosphorus content on indicators of bone growth in lambs. Exp. Physiol. 1997, 82, 193-202. [CrossRef]

34. Schröder, B.; Käppner, H.; Failing, K.; Pfeffer, E.; Breves, G. Mechanisms of intestinal phosphate transport in small ruminants. Br. J. Nutr. 1985, 74, 635-648. [CrossRef]

35. Kichura, T.S.; Horst, R.L.; Beitz, D.C.; Littledike, E.T. Relationships between prepartal dietary calcium and phosphorus, vitamin D metabolism, and parturient paresis in dairy cows. J. Nutr. 1982, 112, 480-487. [CrossRef]

36. Barton, B.A.; Jorgensen, N.A.; DeLuca, H.F. Impact of prepartum dietary phosphorus intake on calcium homeostasis at parturition. J. Dairy Sci. 1987, 70, 1186-1191. [CrossRef] 